\title{
PERSEPSI MASYARAKAT MENGENAI PROGRAM DHARMA DALAM MENCEGAH PENYAKIT RABIES DI WILAYAH SANUR KECAMATAN DENPASAR SELATAN 2019
}

\author{
Desak Nilam Yugiutami*, I Made Subrata \\ Program Studi Sarjana Kesehatan Masyarakat Fakultas Kedokteran Universitas Udayana \\ desaknilam09@gmail.com
}

\begin{abstract}
ABSTRAK
Program Dharma yaitu sebuah program yang menggunakan konsep One Health untuk mengatasi masalah rabies. Kegiatan yang dilakukan meliputi edukasi rabies, layanan hotline/kader dan vaksinasi rabies. Program Dharma telah dilaksanakan di wilayah Sanur sejak 2016, di Desa Sanur Kaja, Sanur Kauh dan Kelurahan Sanur. Namun, belum pernah dilakukan penelitian mengenai persepsi masyarakat terhadap Program Dharma, dimana dalam pelaksanaan Program Dharma tentu akan menimbulkan berbagai macam persepsi dari masyarakat. Tujuan penelitian untuk mengetahui persepsi masyarakat mengenai Program Dharma di wilayah Sanur. Desain penelitian adalah crosssectional deskriptif dengan populasi yaitu seluruh masyarakat di Desa Sanur Kaja, Sanur Kauh dan Kelurahan Sanur, dengan sampel sebesar 107 KK dan responden kepala keluarga menggunakan teknik purposive sampling. Analisis data menggunakan analisis univariat. Hasil penelitian diketahui bahwa persepsi masyarakat terhadap kegiatan vaksinasi, edukasi rabies dan layanan hotline/kader dari Program Dharma memiliki persepsi baik (100\%). Hasil ini menunjukkan bahwa kegiatan Program Dharma diterima dan dipersepsikan dengan baik oleh masyarakat. Oleh karena itu, kegiatan program dharma perlu dioptimalkan agar dapat berjalan lebih baik lagi untuk memenuhi keperluan masyarakat dalam upaya pencegahan rabies.
\end{abstract}

Kata Kunci : Persepsi, Program Dharma, Penyakit Rabies

\begin{abstract}
Program Dharma is a the program that uses the concept of one health to address the problem of rabies. The activities of Program Dharma is rabies education, hotline service and the rabies vaccine. Program Dharma has been done in the region sanur since 2016, in the Sanur Kaja village, Sanur Kauh village and Sanur. But, the implementation of dharma program for 3 years, has never done research on the public perception of the program dharma, where in the implementation of the program dharma would have potential to cause various perception of the community. The purpose of research is to know the public perception of the Program Dharma in sanur areas.A design research is crosssectional descriptive with a population is the whole community in the Sanur Kaja village, Sanur Kauh village and Sanur, with a sample of $107 \mathrm{KK}$ and the respondents is family head using purposive sampling. Data analysis using analysis univariat. The results of the study discovered that people perceptions of the vaccination, education and hotline service of Program Dharma have good perception (100\%). This result indicate that Program Dharma acceptable and perceived by public. Therefore, Program Dharma need to optimized to be better to fulfill the need of the public to prevent rabies.
\end{abstract}

Keywords: Perception, Program Dharma, Rabies

\section{PENDAHULUAN}

Rabies merupakan penyakit paling tua yang dikenal di manusia. Masih belum ada pengobatan yang tersedia jika seorang pasien telah menunjukkan gejala-gejala rabies. Rabies adalah penyakit yang ditularkan dari hewan ke manusia (zoonosis) yang disebabkan oleh virus yang menyerang semua hewan berdarah panas dan juga manusia. Terdapat dua bentuk manifestasi klinis rabies yaitu galak dan paralitik (lumpuh). Utamanya virus rabies ditularkan dari air liur hewan rabies ketika hewan tersebut menggigit atau mencakar seseorang. Jilatan pada luka atau goresan dan kulit yang tidak utuh, 
atau pada lapisan mulut dan hidung juga dapat menularkan penyakit (World Health Organization, 2013).

Menurut World Health Organization, diperkirakan 55.000 orang di dunia meninggal akibat rabies setiap tahunnya dan sekitar 56\% terjadi di Asia dan 44\% terjadi di Afrika khususnya di daerah pedesaan di kedua benua (World Health Organization, 2015). Rabies masih bersifat endemik di 72 negara dan masih terjadi di 92 negara dan lebih dari 99\% kasus rabies pada manusia terjadi akibat gigitan anjing yang terinfeksi virus rabies. Perkiraan secara global menunjukkan bahwa kematian manusia (disebabkan endemik rabies dengan penularan oleh anjing) tertinggi di Asia, dengan insiden kematian tertinggi dilaporkan di India dan Afrika (Kementerian Kesehatan RI, 2017).

Di Indonesia terdapat 25 provinsi yang tertular rabies dan hanya 9 provinsi yang dinyatakan bebas rabies yaitu Papua, Papua Barat, Kepulauan Bangka Belitung, Kepulauan Riau, dan Nusa Tenggara Barat, DI Yogyakarta, Jawa Tengah, Jawa Timur dan DKI Jakarta. (Kementerian Kesehatan RI, 2018a). Rabies di Indonesia merupakan penyakit hewan yang penting dan termasuk ke dalam penyakit hewan menular strategis prioritas karena berdampak terhadap sosial ekonomi dan kesehatan masyarakat serta kejadian pada hewan maupun manusia yang terinfeksi selalu diakhiri dengan kematian (Case Fatality Rate $100 \%$ ) sehingga penyakit ini menimbulkan rasa takut dan kekhawatiran bagi masyarakat (Kementerian Kesehatan RI, 2017).

Kasus kematian manusia akibat rabies dan kasus gigitan HPR (Hewan Penular
Rabies) mengalami penurunan dari tahun 2015 dibandingkan dengan 2017. Jumlah rata-rata per tahun kasus kematian manusia akibat rabies di Indonesia selama tiga tahun terakhir (2015-2017) sebanyak 108 kasus, untuk kasus gigitan HPR dalam tiga tahun terakhir (2015-2017) sebanyak 74.306 kasus (Kementerian Kesehatan RI, 2018a). Rabies di Indonesia termasuk salah satu penyakit strategis nasional yang telah menyebar ke hampir seluruh wilayah termasuk Provinsi Bali (Nugoro, Pudjiatmoko, I.K, S, \& L, 2013).

Provinsi Bali merupakan provinsi yang dinyatakan sebagai salah satu daerah tertular rabies. Rabies diperkirakan masuk ke Bali pertama kali di Semenanjung Bukit, Kabupaten Badung pada Bulan April 2008 (Supartika et al., 2009). Kasus kematian manusia akibat rabies di Bali menurun dari tahun 2015 sebanyak 15 kasus, 2016 sebanyak 5 kasus dan 2017 sebanyak 2 kasus. Namun, Bali merupakan provinsi dengan kasus gigitan HPR tertinggi pada tahun 2017, dengan rata-rata jumlah kasus gigitan HPR tiga tahun terakhir (2015-2017) sebanyak 35.518 kasus. Pemerintah provinsi Bali sendiri telah melakukan berbagai upaya dalam pengendalian rabies dan dinas peternakan serta badan pemberdayaan (desa pekraman/desa adat), menerbitkan Perda No. 15 Tahun 2009 tentang pengendalian rabies di Provinsi Bali yang mengatur tata cara pemeliharaan HPR, mengatur peredaran HPR. Permasalahan yang terjadi yaitu peran serta masyarakat dalam penanganan rabies baik dari sektor kesehatan dan peternakan belum optimal, hewan positif rabies dan desa tertular meningkat, tahun 2013-2014 kasus 
kematian dapat ditekan tetapi 2015 kembali meningkat (Dinas Kesehatan Provinsi Bali, 2018).

Dari 9 kabupaten yang terdapat di Bali, Kota Denpasar merupakan kabupaten/kota dengan kasus gigitan HPR terendah dengan rata-rata kasus selama tiga tahun terakhir (2016-2018) sebanyak 647 kasus gigitan HPR (Kementerian Kesehatan RI, 2018b). Wilayah Sanur, Kecamatan Denpasar Selatan merupakan daerah pariwisata yang dianggap bebas rabies, walaupun pada tahun 2016 dan 2017 masih terdapat kasus gigitan HPR di Denpasar Selatan, tetapi tidak terdapat kasus positif rabies. Hal ini menjadikan Sanur sebagai wilayah percontohan (pilot project) (Utami et al., 2017)

Program Dharma yaitu sebuah program yang menggunakan konsep One Health untuk mengatasi masalah rabies. Kegiatan Program Dharma yaitu, edukasi rabies, vaksinasi rabies, transect, mapping $\mathcal{E}$ revisit, health day dan layanan hotline. Tujuan Program Dharma untuk memberdayakan masyarakat agar dapat berpartisipasi dalam mencegah dan memberantas rabies. Tujuan Program Dharma sejalan dengan Suartha et al (2012), yang mengungkapkan pengendalian penyakit rabies tidak hanya bergantung pada masalah anjing tetapi juga menyangkut masalah manusia. Keberhasilan pengendalian dan pemberantasan anjing pada dasarnya bergantung pada tingkat pemahaman masyarakat tentang penyakit rabies (Suartha, Anthara, Putra, \& Rita, 2012). Masyarakat merupakan faktor utama dalam menentukan keberhasilan dari pengendalian dan pencegahan rabies di suatu daerah. Pengetahuan, sikap dan perilaku masyarakat yang kurang menjadikan mereka rentan terhadap penularan rabies (Direktorat Kesehatan Hewan, 2004). Program Dharma telah dilaksanakan di wilayah Sanur sejak 2016, tepatnya di Desa Sanur Kaja, Desa Sanur Kauh dan Kelurahan Sanur. Selama pelaksanaan tersebut, penelitian yang dilakukan oleh Program Dharma hanya membahas mengenai ekologi anjing dan pengetahuan rabies oleh pemilik anjing dan bukan pemilik anjing yang didapatkan hasil populasi anjing berdasarkan sensus di Sanur sebanyak 6009 ekor, dengan 5809 ekor (96,7\%) merupakan anjing berpemilik dan 200 ekor $(3,3 \%)$ merupakan anjing tidak berpemilik (Hiby et al., 2018). Namun, selama 3 tahun dilaksanakannya Program Dharma, belum pernah dilakukan penelitian mengenai persepsi masyarakat terhadap Program Dharma, dimana dalam pelaksanaan Program Dharma tentu akan menimbulkan berbagai macam persepsi dari masyarakat di Desa Sanur Kaja, Desa Sanur Kauh dan Kelurahan Sanur. Menurut Mulyana (2008) dalam Idayanti (2017) menyatakan istilah persepsi sering juga disebut sebagai anggapan, pandangan atau gambaran. Sebab dalam persepsi terdapat tanggapan seseorang mengenai suatu hal atau objek. Maka dari itu peneliti ingin mengetahui persepsi masyarakat mengenai kegiatan vaksinasi rabies, layanan hotline/kader dan edukasi rabies dari Program Dharma di wilayah Sanur karena ketiga kegiatan tersebut berkaitan langsung dengan masyarakat. 


\section{METODE PENELITIAN}

Jenis rancangan penelitian yang digunakan adalah penelitian cross sectional deskriptif dengan melihat persepsi masyarakat mengenai Program Dharma dalam mencegah rabies di wilayah Sanur, Kecamatan Denpasar Selatan. Variabel dalam penelitian ini adalah persepsi masyarakat mengenai Program Dharma dengan populasi target yaitu seluruh masyarakat Kelurahan Sanur, Desa Sanur Kaja, dan Desa Sanur Kauh dan populasi terjangkau yaitu seluruh masyarakat di Kelurahan Sanur, Desa Sanur Kaja, dan Desa Sanur Kauh yang tercatat dalam data penduduk di Kantor Desa/Kelurahan. Sampel dalam penelitian ini adalah KK dengan sampel sebesar $107 \mathrm{KK}$.

Teknik penentuan responden menggunakan purposive sampling dengan responden yaitu kepala keluarga. Kriteria inklusi penelitian ini yaitu bertempat tinggal di Kelurahan Sanur, Sanur Kaja

Tabel 1. Distribusi Frekuensi Karakteristik Responden Menurut Umur dan Jenis Kelamin dan Sanur Kauh, berusia 26 sampai $>65$ tahun, merupakan kepala keluarga, bersedia menjadi responden, pernah mendengar atau mendapatkan kegiatan dari Program Dharma. Kriteria eksklusi dalam penelitian ini yaitu responden yang saat pengambilan data tidak ada di rumah atau sedang sakit.

Jenis data yang dikumpulkan dalam penelitian ini yaitu data primer dan data sekunder. Data primer adalah data yang diambil dari sumbernya langsung dengan wawancara menggunakan daftar pertanyaan melalui kuesioner. Data sekunder adalah data yang diambil peneliti dari Program Dharma. Teknik analisis data menggunakan teknik analisis univariat.

\section{HASIL PENELITIAN}

Berikut adalah distribusi frekuensi karakteristik responden dalam penelitian ini :

\begin{tabular}{lll}
\hline Karakteristik Responden & $\mathbf{n}$ & $\mathbf{\%}$ \\
\hline Umur (tahun) & & \\
$26-45$ & 50 & 46,73 \\
$>45$ & 57 & 53,27 \\
Pendidikan & & \\
$\quad$ Dasar & 20 & 18,69 \\
Menengah & 57 & 53,27 \\
Tinggi & 30 & 28,04
\end{tabular}

Karakteristik reponden berdasarkan umur dibagi menjadi 2 kategori yang terdiri dari kelompok umur 26-45 tahun berjumlah 50 orang $(46,73 \%)$ dan kelompok umur $>45$ tahun berjumlah 57 orang $(53,27 \%)$. Berdasarkan tabel diatas, dapat dilihat bahwa tingkat pendidikan terakhir responden dibagi menjadi 3 kategori yaitu pendidikan dasar berjumlah 
20 orang $(18,69 \%)$, pendidikan menengah sebanyak 57 orang $(53,27 \%)$ dan pendidikan tinggi sebanyak 30 orang $(28,04 \%)$.

Tabel 2. Distribusi Frekuensi Responden mengetahui Kegiatan Program Dharma

\begin{tabular}{|c|c|c|}
\hline Variabel & $\mathbf{n}$ & $\%$ \\
\hline \multicolumn{3}{|l|}{ Program Edukasi Rabies } \\
\hline Pernah & 89 & 83,18 \\
\hline Tidak Pernah & 18 & 16,82 \\
\hline \multicolumn{3}{|l|}{ Program Layanan Hotline/Kader } \\
\hline Pernah & 54 & 50,47 \\
\hline Tidak Pernah & 53 & 49,53 \\
\hline \multicolumn{3}{|l|}{ Program Vaksinasi Rabies } \\
\hline Pernah & 107 & 100 \\
\hline Tidak Pernah & 0 & 0 \\
\hline $\begin{array}{l}\text { Berdasarkan tabel diatas, diketahui } \\
\text { bahwa responden yang pernah } \\
\text { mendapatkan edukasi rabies sebanyak } 89 \\
\text { orang }(83,18 \%) \text {, yang pernah mendengar } \\
\text { adanya layanan hotline/kader sebanyak } 54\end{array}$ & & $\begin{array}{l}\text { orang }(50,47 \%) \text { dan pernah mendengar } \\
\text { adanya kegiatan vaksinasi rabies yang } \\
\text { bekerjasama dengan Dinas Pertanian Kota } \\
\text { Denpasar dan Yayasan } B A W A \text { sebanyak } \\
107 \text { orang }(100 \%) \text {. }\end{array}$ \\
\hline
\end{tabular}

Tabel 3. Distribusi Frekuensi Persepsi terhadap Kegiatan Vaksinasi Rabies, Edukasi Rabies dan Layanan Hotline/Kader

\begin{tabular}{|c|c|c|}
\hline Persepsi & $\mathbf{n}$ & $\%$ \\
\hline \multicolumn{3}{|l|}{ Vaksinasi Rabies } \\
\hline Baik & 107 & 100 \\
\hline Tidak Baik & 0 & 0 \\
\hline \multicolumn{3}{|l|}{ Edukasi Rabies } \\
\hline Baik & 89 & 100 \\
\hline Tidak Baik & 0 & 0 \\
\hline \multicolumn{3}{|l|}{ Layanan Hotline/Kader } \\
\hline Baik & 54 & 100 \\
\hline Tidak Baik & 0 & 0 \\
\hline $\begin{array}{l}\text { Persepsi dalam penelitian ini dibagi } \\
\text { menjadi } 2 \text { kategori yaitu persepsi baik dan } \\
\text { persepsi tidak baik. Hasil dari tabel diatas } \\
\text { menunjukkan bahwa persepsi seluruh }\end{array}$ & & $\begin{array}{l}\text { responden terhadap kegiatan vaksinasi } \\
\text { rabies, edukasi rabies dan layanan } \\
\text { hotline/kader memiliki persepsi baik } \\
(100 \%) \text {. }\end{array}$ \\
\hline
\end{tabular}


Tabel 4. Distribusi Frekuensi Tanggapan Responden terhadap Item Pernyataan Vaksinasi Rabies

\begin{tabular}{lll}
\hline Tanggapan Responden & $\mathbf{n}$ & \% \\
\hline Vaksinasi Rabies & & \\
\hline Mencegah Rabies & 68 & 63,55 \\
$\quad$ Sangat Setuju & 39 & 36,45 \\
$\quad$ Setuju & 0 & 0 \\
Tidak Setuju & 0 & 0 \\
$\quad$ Sangat Tidak Setuju & & \\
Manfaat Vaksinasi Rabies & 65 & 60,75 \\
$\quad$ Sangat Setuju & 42 & 39,25 \\
Setuju & 0 & 0 \\
$\quad$ Tidak Setuju & 0 & 0 \\
Sangat Tidak Setuju & & \\
Kelanjutan Vaksinasi Rabies & 89 & 83,18 \\
Sangat Setuju & 18 & 16,82 \\
Setuju & 0 & 0 \\
Tidak Setuju & 0 & 0 \\
Sangat Tidak Setuju & &
\end{tabular}

Berdasarkan tabel diatas, tanggapan terhadap pernyataan yaitu "Pemberian vaksinasi rabies dari Program Dharma membantu dalam mencegah rabies di wilayah Sanur" yang menjawab sangat setuju sebanyak $63,55 \%$ dan $36,45 \%$ menjawab setuju.

Dari seluruh responden yang menjawab pernyataan yaitu "Bapak merasakan manfaat dari adanya kegiatan vaksinasi rabies oleh Program Dharma" didapatkan yang menjawab sangat setuju sebanyak $60,75 \%$ dan $39,25 \%$ menjawab setuju.

Berdasarkan tabel diatas, tanggapan terhadap pernyataan yaitu "Bagaimana pendapat Bapak tentang kelanjutan kegiatan vaksinasi rabies dari Program Dharma ?" yang menjawab sangat setuju sebanyak $83,18 \%$ dan $16,82 \%$ menjawab setuju. 
Tabel 5. Distribusi Frekuensi Tanggapan Responden terhadap Item Pernyataan Edukasi Rabies

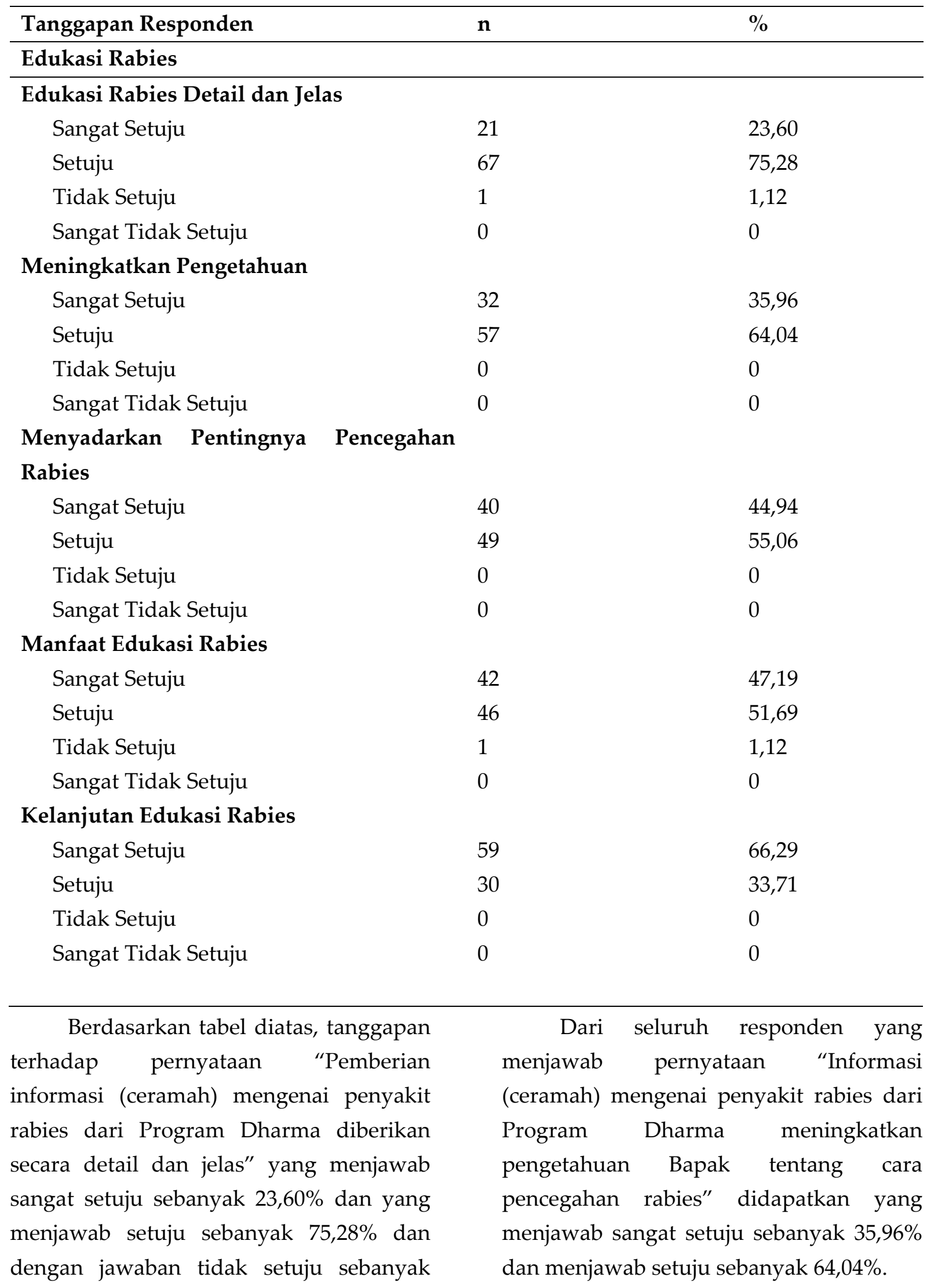
$1,12 \%$. 
Berdasarkan tabel diatas, tanggapan terhadap pernyataan "Informasi (ceramah) mengenai penyakit rabies dari Program Dharma menyadarkan Bapak mengenai pentingnya pencegahan rabies" yang menjawab sangat setuju sebanyak $44,94 \%$ dan jawaban setuju sebanyak $55,06 \%$.

Dari seluruh responden yang menjawab pernyataan "Bapak merasakan manfaat dari adanya kegiatan pemberian informasi (ceramah) tentang penyakit rabies oleh Program Dharma" didapatkan yang menjawab sangat setuju sebanyak $47,19 \%$, jawaban setuju sebanyak 51,69\% dan dengan jawaban tidak setuju sebanyak $1,12 \%$.

Berdasarkan tabel diatas, tanggapan terhadap pertanyaan "Bagaimana pendapat Bapak tentang kelanjutan pemberian informasi (ceramah) mengenai rabies dari Program Dharma ?" yang menjawab sangat setuju sebanyak $66,29 \%$ dan 33,71\% menjawab setuju.

Tabel 6. Distribusi Frekuensi Tanggapan Responden terhadap Item Pernyataan Layanan Hotline/ Kader Program Dharma

\begin{tabular}{lcc}
\hline \multicolumn{1}{c}{ Tanggapan Responden } & n & \% \\
\hline Layanan Hotline/Kader & & \\
\hline Membantu Menyelesaikan Masalah & & \\
Anjing & 24 & 44,44 \\
$\quad$ Sangat Setuju & 30 & 55,56 \\
Setuju & 0 & 0 \\
Tidak Setuju & 0 & 0 \\
Sangat Tidak Setuju & & 51,85 \\
Manfaat Layanan Hotline/Kader & 28 & 48,15 \\
Sangat Setuju & 26 & 0 \\
Setuju & 0 & 0 \\
Tidak Setuju & 0 & \\
Sangat Tidak Setuju & & 74,07 \\
Kelanjutan Layanan Hotline/Kader & 40 & 25,93 \\
Sangat Setuju & 14 & 0 \\
Setuju & 0 & 0 \\
Tidak Setuju & 0 &
\end{tabular}

Berdasarkan tabel diatas, tanggapan terhadap pernyataan yaitu “Layanan Hotline/Kader Dharma dari Program Dharma membantu memberikan solusi terkait masalah anjing di wilayah Sanur" yang menjawab sangat setuju sebanyak $44,44 \%$ dan $55,56 \%$ menjawab setuju.

Dari seluruh responden yang menjawab pernyataan "Bapak merasakan manfaat dari adanya kegiatan Layanan 
Hotline/kader oleh Program Dharma" didapatkan yang menjawab sangat setuju sebanyak $51,85 \%$ dan $48,15 \%$ menjawab setuju.

Berdasarkan tabel diatas, tanggapan terhadap pertanyaan yaitu "Bagaimana pendapat Bapak tentang kelanjutan layanan Hotline dari Program Dharma" yang menjawab sangat setuju sebanyak $74,07 \%$ dan $25,93 \%$ menjawab setuju.

\section{DISKUSI}

Berdasarkan hasil dari 107 responden, diketahui mayoritas responden berada pada kelompok umur $>45$ tahun dan mayoritas responden memiliki pendidikan terakhir pada kategori pendidikan menengah sebanyak 57 orang $(53,27 \%)$, terbanyak kedua yaitu pendidikan tinggi sebanyak 30 orang $(28,04 \%)$ dan terakhir pendidikan dasar sebanyak 20 orang (18,69\%). Notoatmodjo

$$
\text { dalam Fariati }
$$
mengungkapkan bahwa pendidikan berdampak pada peningkatan pengetahuan seseorang. Slamet (2003) dalam Tuty et al (2017) juga menyatakan bahwa, tingkat pendidikan akan mempengaruhi nilai-nilai yang dianutnya, cara berfikir, cara pandang bahkan persepsinya terhadap suatu masalah (Slamet, 2003).

Hasil persepsi terhadap kegiatan vaksinasi rabies, edukasi rabies dan layanan hotline/kader memiliki persepsi yang baik (100\%). Persepsi dapat disebabkan oleh beberapa faktor. Salah satu faktor yang mempengaruhi persepsi yaitu faktor fungsional, dimana pengalaman masa lalu merupakan bagian dari faktor fungsional. Pengalaman masa lalu responden kemungkinan dapat mempengaruhi persepsi terhadap kegiatan Program Dharma. Pengalaman masa lalu yang menyenangkan dan mendapatkan layanan dari Program Dharma yang sesuai dengan kebutuhan responden dapat menyebabkan munculnya persepsi baik terhadap Program Dharma.

Persepsi baik terhadap Program Dharma dapat dilihat dari tanggapan responden terhadap pernyataanpernyataan yang diajukan. Responden menyatakan sangat setuju (83,18\%) apabila kegiatan vaksinasi rabies dari program dharma tetap harus dilanjutkan dan $16,82 \%$ sisanya menyatakan setuju untuk melanjutkan kegiatan vaksinasi rabies. Responden juga menyatakan sangat setuju $(60,75 \%)$ bahwa pemberian vaksinasi rabies ini memberikan manfaat kepada dirinya serta $63,55 \%$ menyatakan sangat setuju bahwa kegiatan vaksinasi dapat membantu mencegah adanya rabies di wilayah Sanur. Jawaban responden terhadap pemberian vaksinasi rabies ini dapat menjadi tanda bahwa responden sudah memiliki kepedulian dan sadar bahwa salah satu cara dalam mencegah rabies yaitu dengan pemberian vaksinasi rabies, hal ini sesuai dengan yang dinyatakan oleh Lembo et al., (2010) dan Wunner dan Briggs (2010) dalam Dibia, dkk (2015) yang menyatakan bahwa vaksinasi rabies merupakan pendekatan yang paling efektif dalam pengendalian rabies baik dari manusia maupun hewan (Lembo et al, 2010) (Wunner WH, 2010). 
Hasil juga menunjukkan bahwa seluruh responden (100\%) mengetahui adanya kegiatan vaksinasi rabies dari Program Dharma yang bekerjasama dengan Dinas Pertanian Kota Denpasar dan Yayasan $B A W A$. Hal ini kemungkinan disebabkan karena Program Dharma sudah berjalan selama 3 tahun dan penyebaran informasi mengenai kegiatan vaksinasi rabies yang dilakukan melalui media sosial sehingga informasi lebih mudah diketahui oleh masyarakat.

Berdasarkan hasil dari 107 responden, diketahui terdapat 89 responden yang pernah mendapatkan edukasi rabies dari program dharma dan mayoritas reponden setuju (75,28\%) bahwa pemberian edukasi rabies telah diberikan secara detail dan jelas. Namun, terdapat responden $(1,12 \%)$ menyatakan tidak setuju bahwa edukasi rabies diberikan secara detail dan jelas. Hal ini menunjukkan bahwa sebagian besar responden mengerti dan memahami edukasi rabies dari Program Dharma sehingga pengetahuan masyarakat dapat meningkat. Hal ini dibuktikan dengan jawaban responden yang setuju $(64,04 \%)$ bahwa edukasi rabies meningkatkan pengetahuan dan responden juga setuju $(55,06 \%)$ edukasi rabies dapat menyadarkan pentingnya pencegahan rabies. Maulana (2009) dalam Supit (2018) mangatakan bahwa tujuan pendidikan kesehatan adalah untuk meningkatkan pengetahuan, mengubah sikap, dan mengarahkan perilaku yang diinginkan oleh kegiatan (Maulana, 2009). Hal ini berarti pemberian edukasi rabies dari program dharma dilihat dari jawaban responden telah dapat meningkatkan pengetahuan responden.

Peningkatan pengetahuan responden juga didukung oleh penelitian yang dilakukan oleh Hiby, et al (2018) yang mendapatkan hasil bahwa pengetahuan masyarakat Sanur setelah adanya Program Dharma, sebagian besar telah akurat terhadap pertanyaanpertanyaan yang harus dilakukan setelah tergigit anjing dengan presentase menjawab pergi ke klinik yaitu 73,9\%, membasuh luka dengan sabun dan air mengalir $27,9 \%$, mendapat vaksin $15,2 \%$, membasuh luka selama 15 menit dan memberi tahu klian $0,1 \%$ serta pengetahuan mengenai gejala rabies pada anjing sebagian besar juga telah menjawab dengan benar, dimana 40,3\% menjawab air liur berlebih, 9,2\% menjawab berkelakuan aneh dan menggigit tanpa alasan. Adanya peningkatan pengetahuan dari masyarakat berarti masyarakat sudah mengetahui tindakan-tindakan yang dilakukan untuk pencegahan rabies. Sesuai dengan yang dinyatakan oleh Nurrohman et al (2017) bahwa masyarakat diharapakan memiliki pengetahuan tentang rabies yang cukup karena dukungan aktif dari masyarakat merupakan bagian penting dalam mencegah, menanggulangi dan memberantas rabies (Nurrohman, Batan, \& Kardena, 2017). Responden juga menyatakan bahwa mereka sangat setuju $(47,19 \%)$ pemberian edukasi rabies memberikan manfaat bagi dirinya. Namun, terdapat responden (1,12\%) menyatakan pemberian edukasi rabies tidak bermanfaat bagi dirinya, tetapi 
sebagian besar responden sangat setuju $(66,29 \%)$ apabila kegiatan edukasi rabies dilanjutkan. Sedangkan 18 responden yang tidak pernah mendapat edukasi rabies kemungkinan saat pemberian edukasi, responden tersebut sedang bekerja sehingga tidak dapat menghadiri saat pemberian edukasi dilakukan di banjar-banjar atau saat pemberian edukasi door to door.

Berdasarkan hasil penelitian, juga diketahui bahwa responden yang mengetahui adanya layanan hotline/kader Program Dharma sebesar 50,47\%. Responden yang mengetahui adanya layanan hotline/kader kemungkinan pernah menghubungi layanan hotline/kader untuk mengatasi masalah terkait anjing seperti masalah pada anjing peliharaannya atau masalah pada anjing di lingkungan sekitarnya, dimana dari 54 responden menjawab setuju (55,56\%) bahwa layanan hotline/kader dapat membantu dalam menyelesaikan masalah anjing di wilayah Sanur. Teori layanan kesehatan dalam Ciamy (2016) mengemukakan bahwa pelayanan kesehatan yang bermutu ditinjau dari sudut pandang pasien dan masyarakat berarti suatu empati, respek dan tanggap akan kebutuhannya. Apabila pelayanan kesehatan dalam hal ini yaitu layanan hotline/kader sebanding dengan harapan maka pelanggan dalam hal ini adalah masyarakat akan puas, apabila kurang dari harapan maka masyarakat tidak puas, serta apabila melebihi harapan maka masyarakat akan amat sangat puas (Ciamy, 2016). Hal ini berarti layanan hotline/kader dari program dharma sudah melakukan pelayanan yang sesuai dengan harapan masyarakat.

Selain itu, masyarakat juga merasakan manfaat dari adanya layanan hotline/kader Program Dharma yang dilihat dari jawaban responden yang menyatakan sangat setuju (51,85\%) bahwa layanan hotline/kader memberikan manfaat bagi dirinya. Manfaat yang dirasakan masyarakat tidak terlepas dari kinerja yang diberikan oleh layanan hotline/kader yang sudah bertugas dalam memenuhi keperluan masyarakat terkait pencegahan rabies, yang berarti layanan hotline/kader telah memberikan kinerja yang baik sesuai dengan pernyataan Dikson et al (2017) yang menyatakan bahwa peran kader yang diharapkan yaitu dapat menjembatani antara petugas/ahli kesehatan dengan masyarakat serta membantu masyarakat dalam menghadapi atau menjawab kebutuhan kesehatan mereka sendiri dan juga diharapkan dapat menyediakan informasi kepada pejabat berwenang yang mungkin tidak dapat mencapai masyarakat langsung serta mampu mendorong para pejabat kesehatan di sistem kesehatan agar mengerti dan merespon kebutuhan masyarakat (Dikson, Suprojo, \& Adiwidjaja, 2017). Responden juga menyatakan sangat setuju (74,07\%) dengan kelanjutan adanya layanan hotline/kader. Sedangkan 49,53\% responden yang tidak mengetahui layanan hotline/kader dapat disebabkan karena responden yang menemui masalah terkait anjing tidak menghubungi kader/layanan hotline, melainkan langsung ke tenaga kesehatan atau responden tidak pernah 
menemui masalah terkait anjing sehingga mereka tidak sadar bahwa terdapat layanan hotline/kader yang dapat dihubungi. Maka dari itu, pengenalan mengenai adanya layanan hotline/kader perlu dioptimalkan saat pendataan anjing (revisit) agar masyarakat mengetahui bahwa terdapat layanan hotline/kader dari program dharma sehingga dapat dimanfaatkan secara maksimal.

\section{SIMPULAN}

Persepsi masyarakat terhadap kegiatan vaksinasi rabies, edukasi rabies dan layanan hotline/kader dari Program Dharma memiliki persepsi baik (100\%),

\section{SARAN}

Berdasarkan simpulan diatas maka dapat disarankan untuk mengoptimalkan pelaksanaan Program Dharma dalam pemberian vaksinasi rabies, pemberian edukasi rabies dan keaktifan kader/layanan hotline agar dapat berjalan lebih baik lagi untuk memenuhi kebutuhan masyarakat dalam upaya pencegahan rabies.

\section{DAFTAR PUSTAKA}

Ciamy, N. U. (2016). Hubungan Persepsi Lansia Tentang Peran Kader Dengan Intensitas Kunjungan Ke Posyandu Lansia Di Dusun Degolan Bumirejo Lendah Kulon Progo Yogyakarta. Pendidikan Guru Sekolah Dasar, 5(1), 20-25. Retrieved from http://eprints.ums.ac.id/25264/

Dikson, A., Suprojo, A., \& Adiwidjaja, I. (2017). Peran Kader Posyandu Terhadap Pembangunan Kesehatan Masyarakat. Kesehatan Masyarakat,

$$
6(1), 60-62 .
$$

Dinas Kesehatan Provinsi Bali. (2018). Profil Kesehatan Provinsi Bali 2017.

Direktorat Kesehatan Hewan. (2004). Pedoman Pencegahan dan Pemberantasan Penyakit Hewan Menular. Jakarta: Departemen Pertanian.

Hiby, E., Agustina, K. K., Atema, K. N., Bagus, G. N., Girardi, J., Harfoot, M., ... Wirawan, D. N. (2018). Dog Ecology and Rabies Knowledge of Owners and Non-Owners in Sanur, A Sub-District of the Indonesian Island Province of Bali. (July). https://doi.org/10.3390/ani8070112

Kementerian Kesehatan RI. (2017). Infodatin Situasi Rabies di Indonesia.

Kementerian Kesehatan RI. (2018a). Profil Kesehatan Indonesia 2017.

Kementerian Kesehatan RI. (2018b). Sistem Kewaspadaan Dini dan Respon GHPR.

Maulana, H. (2009). Promosi Kesehatan Edisi 2. In EGC.

Nugoro, D. K., Pudjiatmoko, I.K, D., S, T., \& L, S. (2013). Analisis Data Surveilans Rabies (2008-2011) di Propinsi Bali, Indonesia. Outbreak, Surveillance and Investigation Reports (OSIR), 6(2):8-12.

Nurrohman, F. G., Batan, I. W., \& Kardena, I. M. (2017). Perilaku dan Pemahaman Masyarakat Pemelihara Anjing terhadap Risiko Rabies di Kabupaten Karangasem , Bali. Indonesian Medicus Veterinus, 6(5), 386-398. https://doi.org/10.19087/imv.2017.6.5. 386

Slamet. (2003). Belajar dan Faktor-Faktor 
yang Mempengaruhinya. In Cet. IV Jakarta : Rieneka Cipta. https://doi.org/10.20961/carakatani.v3 $2 \mathrm{i} 2.14996$

Suartha, N. I., Anthara, S. M., Putra, I. G. N. ., \& Rita, M. N. (2012). Pengetahuan Masyarakat Tentang Rabies dalam Upaya Bali Bebas Rabies. Buletin Veteriner Udayana. Fakultas Kedokteran Hewan Udayana Bali.

Supartika, I., G, S., K, W., AAG, H. D. P., DMN, D., \& Soegiorto. (2009). Kasus Rabies Pertama Kali di Provinsi Bali. Buletin Veteriner BPPH IV Denpasar 21 (74), 7-12.

Utami, N. W. A., Subrata, I. M., Purnama, S. G., Swacita, I., Agustina, K. K., \& Wirawan, D. (2017). Model Penanggulangan Rabies Berbasis Desa dan Dampaknya pada Populasi Anjing Liar di Sanur. 15-16.
World Health Organization. (2013). Frequently Asked Questions on Rabies. World Health Organization, (September), 1-4. Retrieved from http://www.who.int/rabies/resources/ SEA_CD_278_FAQs_Rabies.pdf?ua =1

World Health Organization. (2015). WHO Recomended Stategies for the Prevention and Control of Communicable Disease. Who/Cdls/Cpe/Smt, 13(7), 107-110. Retrieved from https://apps.who.int/iris/bitstream/ha ndle/10665/67088/WHO_CDS_CPE_S MT_2001.13.pdf

Wunner WH, B. D. (2010). Rabies in the 21st Century. Plos Negl Trop Dis, 4 (3). Retrieved from e591. doi 10.1371/journal.pntd.000591 